\title{
Ethmoiditis with subperiosteal and retro-ocular abscesses due to Aeromonas sobria in a 16-year-old boy exposed to the Ardèche river
}

\author{
A Couturier, ${ }^{1}$ C Chidiac, ${ }^{1,2,3}$ E Truy, ${ }^{2,4}$ T Ferry, $^{1,2,3}$ on behalf of the Lyon \\ BJI Study Group
}

${ }^{1}$ Service de Maladies Infectieuses et Tropicales, Hôpital de la Croix-Rousse, Hospices Civils de Lyon, Lyon, France

${ }^{2}$ Université Claude Bernard Lyon 1, Lyon, France

${ }^{3}$ Centre International de Recherche en Infectiologie (CIRI), Inserm U1111, CNRS UMR5308, ENS de Lyon, UCBL1, Lyon, France ${ }^{4}$ Service d'ORL, Chirurgie de la face et du cou pédiatrique, Hôpital Femme-Mère-enfant, Hospices Civils de Lyon, Lyon, France

\section{Correspondence to} Dr T Ferry, tristan.ferry@univlyon1.fr

Accepted 5 March 2017
CrossMark

To cite: Couturier $A$ Chidiac C, Truy E, et al. BMJ Case Rep Published online: [please include Day Month Year] doi:10.1136/bcr-2017219505

\section{DESCRIPTION}

A 16-year-old boy consulted for fever, left eyelid swelling, headache and vomiting. In the previous weeks, he reported having often bathed in the Ardèche river in France and has made many somersaults in jumping in the water. CT scan demonstrated filling of left ethmoid, maxillary and frontal sinuses with left eyelid infiltration and intraorbital extension. The patient was diagnosed with left ethmoiditis and was treated with intravenous amoxicillin-clavulanate. After 5 days of treatment, his fever had subsided but left exophthalmos, proptosis and ophthalmoplegia appeared with light reflex conservation (figure 1A). Fundus examination of the left eye was unremarkable, and dexamethasone and aminoside eye drops were added. A new CT scan was performed that showed an intraorbital and supraocular collection $(9 \times 23 \mathrm{~mm})$ with left frontal sinus and left ethmoid opacification (figure 1B-D).

The patient was admitted in our clinic and surgical drainage was performed, which confirmed subperiosteal and intraocular abscesses. After surgery, the patient was treated with a combination of cefotaxime and fosfomycin with dexamethasone eye drops. After few days, clinical and biological evolution was favourable with diminution of eyelid swelling, ophthalmoplegia and inflammatory syndrome. Bacterial culture of the abscess found surprisingly several amounts of Aeromonas sobria in culture, and the patient was then treated with ciprofloxacin $500 \mathrm{mg}$ twice a day for 3 weeks. The outcome was favourable.

A

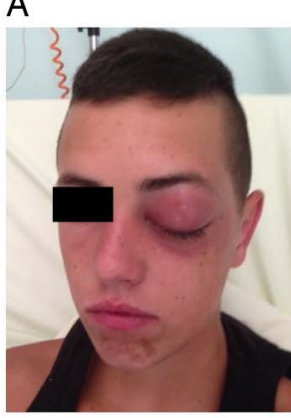

B

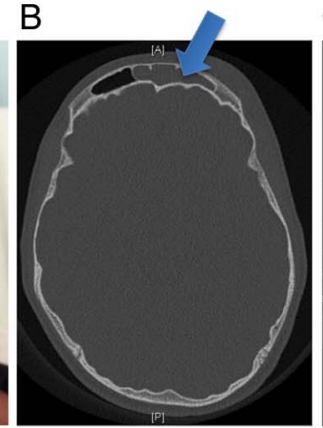

To the best of our knowledge, we present the first known case of complicated ethmoiditis due to Aeromonas species. ${ }^{1}$ Ethmoiditis is a common complication of rhinopharyngitis in children. Complicated forms are less frequent and include subperiosteal abscess, which is a form of bone and joint infection, and orbital abscess with exophthalmos, proptosis and ophthalmoplegia. ${ }^{1-3}$ The most frequent pathogens identified following surgical drainage are Staphylococcus aureus, Streptococci, Haemophilus influenza and anaerobes. A surgical drainage followed by intravenous antibiotics is recommended. ${ }^{1-3}$ Our case underlines that Aeromonas spp. should be listed as an important pathogen in adolescents with complicating ethmoiditis and reporting recently bathing in freshwater rivers.

\section{Learning points}

Ethomiditis can be complicated with subperiosteal and orbital abscess.

- Aeromonas spp. should be listed as an important pathogen in adolescent with complicating ethmoiditis and reporting recently bathing in freshwater rivers.

- Surgical drainage (to clear out the abscess and identifying the pathogen) and intravenous followed by oral adequate antimicrobial therapy are recommended. 
Acknowledgements Lyon Bone and Joint Infection Study Group: Coordinator: Tristan Ferry. Infectious Diseases Specialists - Tristan Ferry, Florent Valour, Thomas Perpoint, André Boibieux, François Biron, Patrick Miailhes, Florence Ader, Agathe Becker, Sandrine Roux, Claire Triffault-Fillit, Fatiha Daoud, Johanna Lippman, Evelyne Braun, Christian Chidiac, Yves Gillet, Laure Hees. Surgeons—Sébastien Lustig, Philippe Neyret, Yannick Herry, Romain Gaillard, Antoine Schneider, Michel-Henry Fessy, Anthony Viste, Philippe Chaudier, Romain Desmarchelier, Tanguy Mouton, Cyril Courtin, Lucy Louboutin, Sébastien Martres, Franck Trouillet, Cédric Barrey, Francesco Signorelli, Emmanuel Jouanneau, Timothée Jacquesson, Ali Mojallal, Fabien Boucher, Hristo Shipkov, Mehdi Ismail, Joseph Chateau. Anesthesiologists-Frédéric Aubrun, Isabelle Bobineau, Caroline Macabéo. Microbiologists - Frederic Laurent, François Vandenesch, Jean-Philippe Rasigade, Céline Dupieux; Nuclear Medicine-Isabelle Morelec, Marc Janier, Francesco Giammarile. PK/PD specialists-Michel Tod, Marie-Claude Gagnieu, Sylvain Goutelle. Prevention of infection-Vincent Ronin, Solweig Gerbier-Colomban, Thomas Benet. Clinical Research Assistant-Eugénie Mabrut
Contributors TF, ET and CC participate to the patient care. AC wrote the case. All authors participated in the literature review and the improvement of the manuscript.

Competing interests None declared.

Patient consent Obtained.

Provenance and peer review Not commissioned; externally peer reviewed.

\section{REFERENCES}

1 DeMuri GP, Wald ER. Complications of acute bacterial sinusitis in children. Pediatr Infect Dis J 2011;30:701-2.

2 Nageswaran S, Woods CR, Benjamin DK Jr, et al. Orbital cellulitis in children. Pediatr Infect Dis J 2006;25:695-9.

3 Chaudhry IA, Al-Rashed W, Arat YO. The hot orbit: orbital cellulitis. Middle East Afr J Ophthalmol 2012;19:34-42.

Copyright 2017 BMJ Publishing Group. All rights reserved. For permission to reuse any of this content visit

http://group.bmj.com/group/rights-licensing/permissions.

BMJ Case Report Fellows may re-use this article for personal use and teaching without any further permission.

Become a Fellow of BMJ Case Reports today and you can:

- Submit as many cases as you like

- Enjoy fast sympathetic peer review and rapid publication of accepted articles

- Access all the published articles

- Re-use any of the published material for personal use and teaching without further permission

For information on Institutional Fellowships contact consortiasales@bmjgroup.com

Visit casereports.bmj.com for more articles like this and to become a Fellow 